\title{
Institutional logics of service provision: the national and urban governance of activation policies in three European countries
}

\author{
Vanesa Fuertes $^{1}$, Ronald William McQuaid ${ }^{2}$, Martin Heidenreich ${ }^{3}$, \\ ${ }^{1}$ University of the West of Scotland, United Kingdom vanesa.fuertes@uws.ac.uk \\ ${ }^{2}$ Stirling Management School, University of Stirling, United Kingdom \\ ronald.mcquaid@stir.ac.uk \\ ${ }^{3}$ University of Oldenburg, Germany, martin.heidenreich@uol.de
}

\begin{abstract}
Labour market activation policies aimed at those with multiple barriers to employment require inter-agency collaboration between local organisations providing social and employment services. This local collaborative context is shaped by different institutional logics (state, markets, professions and community) that are crucial for policy implementation. Using case studies of nine German, UK and Swedish cities, it is argued that different institutional logics help shape the form and operation of local collaboration between different agencies and actors and thus the concrete support for service users at the local level. Although all three countries are characterised by centralised employment policies, each city shows a prevalence, but not exclusivity, of certain institutional logics over others. These differences, partly reflecting the local context, are likely to lead to local variations in understandings of solidarity, policy implementation, inter-agency collaboration and networks of actors and national-local tensions. The paper suggests that an institutional logics approach provides a useful framework for helping to understand local variations and potential national-local policy conflicts.
\end{abstract}

\section{Keywords}

Inter-agency collaboration, active labour market policies, activation, multiple barriers to employment, institutional logics, inter-organisational networks

Word count: 8,751 words including references and Table 1 (350 words), but without the Title page. 


\section{Introduction}

Activation policies aimed at unemployed and economically inactive people with multiple individual and structural barriers to employment, have become increasing complex in their attempts to provide more personalised and effective support (European Commission, 2019). Statistically, these persons are in general classified as long-term unemployed or as workingage recipients of social assistance. Their activation requires greater coordination, both vertically (between sub-national bodies, national and supra-national organisations) and horizontally (across various policy areas), and between public, private or third sector agencies (Kazepov, 2008). Such major organisational challenges, require governance structures that allow the inter-organisational coordination of labour market and other services across policy fields and service providers (McQuaid and Lindsay, 2005), particularly at the local level (Kazepov, 2010) where coordination of activation policy implementation effectively takes place (Heidenreich and Rice, 2016).

This paper investigates the role of different institutional logics in shaping the implementation and coordination of activation policies, at local level, aimed at supporting unemployed jobseekers with multiple barriers to employment. These logics are manifested in the practices, assumptions, values, beliefs and rules by which organisations develop and implement their policies. We suggest that the local institutional logics in each country help explain the variety of local forms of activation delivery and inter-agency working between cities, and that variations between cities and the national institutional logic lead to nationallocal tensions in activation policies aimed at those with multiple barriers. The effectiveness of such activation policies therefore depends not only on the national policy context, but also on the locally specific contexts, including agency competences and resources, and specific forms of dealing with the various needs of the most disadvantaged jobseekers. This raises the question of how this variety of local worlds of activation (Heidenreich and AurichBeerheide, 2014; Jacobsson et al., 2017), i.e. locally specific sets of individual and organised actors, patterns of legitimation, collaboration (networks) and formal and informal rules (institutions), can be understood.

However, activation policies aimed at those with multiple barriers to employment, and in particular the integration of local social and employment services, are not solely a technical or organisational challenge. They are based on different understandings and forms of solidarity which have been characterised by a "mutual responsibility between the individual and society (...) and a normative level of mutual obligations to aid each other" (Bayertz, 1999: 3). Serrano Pascual (2007: 16) argues that social assistance policies (which see individuals as interdependent and vulnerable to exploitation) is conceptually different from solidarity based on labour market attachment (with the individual being responsible for their economic independence and the problem being personal behaviour and attitudes). Activation policies can therefore be seen as aiming at integrating two moral orders which are labelled here as social assistance ${ }^{1}$ and (employment-based) solidaristic support. The organisational, institutional and professional implications of these moral orders are quite different (cf. Leibfried and Tennstedt, 1985 on German poverty and labour policies). A client's reliance on social assistance "means to be stigmatized and to be removed from the ordinary run of men" (Coser, 1965: 145).

1 Social assistance in this context does not refer to the institutional provision of a basic income, but to a moral order characterized by the assistance to the poor and the related stigmatization of the needy (Coser (1965). 
In solidaristic support, the unemployed receive benefits and professional support for their job search. Under flex-security systems this support is based on mutual obligations for job seekers to train and search actively for a new job, but with high income replacement rates and institutional support in return. By combining and integrating organisationally separated logics and approaches, the local implementation of activation policies for those with multiple barriers has to take into account the different local beliefs in the suitable combination of solidarity and social assistance, including the often conflicting social values, assumptions and patterns of legitimation underlying each of them (Leibfried and Tennstedt, 1985). Local agencies are therefore confronted with the differing values and demands of social assistance and solidaristic support and dealing with these conflicting moral orders. In this paper inter-agency co-operation is taken to include formal and informal systems of co-ordination, based either on joint agreements between organisations or collaborative working relationships. They may involve agreements on policy objectives and sharing of responsibility, resources, risks and benefits. For example, it may be important to support a person with multiple barriers to employment to get suitable housing or manage their health condition before improving their vocational and job seeking skills etc. The focus of this paper is on unemployed or inactive, but employable recipients of social (or in the German case: unemployment) assistance who have multiple, and usually severe, barriers to employment (for instance, many long-term unemployed or those with health or disabilities issues.

This paper is based on case studies of nine city regions in the UK, Germany and Sweden, with 166 semi-structured in-depth interviews with key actors at local and national levels. The countries can loosely be considered to represent liberal, corporatist-statist, and social democratic welfare and employment regimes (Esping-Anderson, 1990). They also reflect expectations of different national logics: a market-based logic in the UK; a combination of state and corporatist logics in Germany; and a universalistic state logic in Sweden (Heidenreich et al., 2014).

Section 2 briefly sets out the policy context in terms of increased activation policies, related to those with multiple barriers to employment, and their coordination governance across the European Union and outlines the theoretical contribution of the institutional logics approach to better understand inter-organisational collaboration. Section 3 describes the research design. Section 4 presents the empirical findings, comparing governance across the three cities in each country, within their national activation policy context and resulting intra-country tensions. Section 5 then presents cross-country comparisons between the cities and a wider discussion of the findings. Section 6 presents the conclusions.

\section{The governance of activation policies and institutional logics}

Traditionally, under passive labour market policies, social welfare and labour market policies were frequently weakly connected, which can be interpreted as an attempt to decouple the stylised moral orders of social assistance and solidaristic support previously discussed. The shift towards activation policies has been accompanied by stricter access to passive measures (such as social protection and income transfers) and intensified incentives (e.g. rewards or sanctions) to take part in labour market programmes (Eichhorst et al., 2008: 6). Besides constraining measures, enabling instruments are also used-mostly coordinated, individualised employment and social services, such as job seeking advice or low-level training. This implies a fundamental challenge to previous, centralised governance of labour 
market policies. In many OECD countries, labour market policies and the provision of unemployment benefits are defined and implemented in a uniform and bureaucratic way nationally, while the competences for social policies and welfare provision (frequently linked to other policy areas such as health or housing) are often decentralised to the local/municipal level. Hence, the local organisation of activation policies directly confronts previously decoupled policies based on seemingly opposed logics of social assistance and solidarity.

However, activation policies, aimed at those with multiple barriers to employment, require governance structures that enable closer coordination: of administrative levels and policy fields, such as employability, social assistance, health, housing, childcare, education; and of service providers from the public, private and third sectors (Heidenreich and Rice, 2016; Heidenreich and Aurich-Beerheide, 2014). At the local level, this coordination generally takes the form of inter-agency collaboration which "occurs when people from different organizations, produce something through joint effort, resources, and decision making, and share ownership of the final product or service." (Linden, 2002: 7). Both formal and informal local institutions may support the collaboration of local agencies and the timely and targeted delivery of labour market and social services by reducing the related uncertainties (by personal, direct, trust-based interactions or informal rules), or by providing 'local collective competition goods' (such as tangible infrastructure or intangible aspects such as trust or skills) (Lindsay et al., 2008). Such inter-agency collaboration is socially and institutionally embedded. National and local differences in institutional contexts are therefore important for understanding how activation policies deal with the conflicting goals of helping the most disadvantaged groups and of reintegrating them in the labour market. The institutional logics approach provides a framework for analysing these local institutional contexts in which actors have to deal with the inherent contradictions of stigmatising social assistance and institutionalised solidaristic support for responsible and motivated members of the labour force. While institutional logics have been used to consider policy issues such how state, market and civil society help shape collaboration and public service innovation (Vickers et al., 2017), there have been calls for greater analysis of how logics combine (Skelcher and Smith Rathgeb, 2015). Thornton et al. (2012: 46) designated the institutional context of organisations and networks as an "interinstitutional system" which "regularizes behavior and provides opportunity for agency and change." Within an institutional logics framework, an interinstitutional system is composed of different institutional orders, which can be understood as distinct, ideal typical variants of institutional logics (p. 54), although they and the balances between them may change over time. Seven institutional orders are distinguished: state, markets, professions, corporations, communities, families, and religion (p. 73). For parsimony, family and religion are excluded as these logics are relatively loosely connected to the co-ordination of activation policy and are often omitted in westerncontext research (Johansen and Waldorff, 2017). Corporations, who influence labour demand and existing workers, are also omitted due to the supply-side orientation of most activation policies. So in analysing the institutional embeddedness of activation policies, aimed at helping those with multiple barriers into employment at the local level, we concentrate on four of these institutional orders:

- State: characterised by public policies and administrative rules, legal competences and resources that are essential for decentralised and networked service provision. Their delegation to local public officials also involves local decision-making on conflicting issues 
(for example decisions on which resources are justified for activating unskilled long-term unemployed with major health problems).

- Market: the provision of employment and social services may be based on competition between self-interested agencies or other actors (for instance in 'competition' with other agencies to provide services for different client groups). This might be a strategy for depoliticising the previously mentioned conflicts on the limits and costs of social investment strategies.

- Professions: characterised by personal expertise and professional associations. Interorganisational forms of collaboration often deal with heterogeneous professional backgrounds, for example between those in employment or in social services. These backgrounds may reflect the logics of social assistance or employment-based solidaristic policies by focusing either on individuals needing comprehensive support or unemployed people expecting placement services and unemployment benefits. We treat professional, employee and business associations as part of the professional logic because they represent the interests of the officials and the labour force, but not generally recipients of social assistance.

- Community: "(C)ommunities embody local understandings, norms, and rules" (Thornton et al., 2012: 68). They are characterised by different forms of spatial, social and cultural proximity which facilitate mutual understanding and learning in interagency collaboration. They may be characterised a common vision of the obligations and rights of job-seekers and the local community as illustrated by attitudes towards sanctions for benefit recipients.

Hence our paper considers the basis for distinct sets of local institutional orders and their impact on local patterns of activation policies aimed unemployed jobseekers with multiple barriers.

\section{Methods}

The following analysis is based on local activation policies in nine British, German, and Swedish cities. Within each country, three local case studies were conducted ${ }^{2}$ Some 166 semi-structured interviews were conducted over 2011-12, during recovery from the financial crisis, with representatives of municipalities, local and national government officials, politicians, employment agencies, private, public and third sector providers as well as employer, business and third sector associations. Participant selection was based on responsibilities for the development and/or implementation of activation policies and represented a broad range of views. They lasted between one and two hours and most were recorded, fully or partially transcribed, and thematically analysed (see Heidenreich and Rice, 2016 , for details). The interviews focussed on activation policies: the existence of a coordinated strategy in activation policies; policy development; and implementation. In this

$2 \quad$ See acknowledgments. The study was part of an EU-funded project. Although some specific national policies have changes since the study, we are unaware of any fundamental changes to the general local institutional. 
way, levels of barriers to and facilitators of coordination were explored. The interviews considered: (1) the types of networks used to develop and implement activation policies; (2) the types of actors prominent in them; (3) the approach taken to develop and deliver activation policies; and (4) the structures that underpinned inter-agency relations. Relevant documents were analysed throughout. The three urban regions (NUTS 3 level) in each country were selected on the basis of economic and labour market performance (Table $\mathrm{A} 1$ in the online appendix), reflecting better, worse, or similar performance to national averages of: labour force participation rate, total unemployment rate and regional gross domestic product. The under-performing cities had experienced higher unemployment and declining core industrial sectors (automotive in city S1 in Sweden, the chemicals in formerly socialist (East German) Halle and heavy and shipbuilding industries in Newcastle). This research design allowed comparisons of local variations within one country and between the three countries.

\section{Institutional logics of activation policies at the national and local level}

We now give a short literature-based overview of the national patterns of activation policies in order to determine the type of institutional logics at the country level. We then describe the local context for the inter-organisation coordination of social and employment services in the cities at the core of our empirical analyses.

\subsection{The UK: Centralised and devolved patterns of service-provision}

\section{National context}

The Department for Work and Pensions (DWP) is responsible for UK labour market policies and the administration of out-of-work income benefits. Services for the short-term unemployed are the responsibility of the Public Employment Service's (PES) Jobcentre Plus (JCP), and consists mainly of job-search support and some external specialist assistance for specific groups. Services for the long-term unemployed, and some other groups, are contracted to private or third sector providers through the Work Programme, the flagship national activation programme from 2011 to $2017^{3}$, delivered by fifteen private sector organisations and three public and third sector organisations (Fuertes and McQuaid, 2016). This indicates a national level market-based institutional logic. Work Programme clients receive job-search assistance, short vocational training and work experience (Fuertes et al., 2014). Employment services tend to be mandatory and 'work-first' orientated, with sanctions, such as the removal of benefits, for non-compliance by individuals. The UK's three devolved administrations (Scotland, Wales and Northern Ireland) had varying responsibilities for certain policy areas (such as education and skills, housing, health and social work, economic development and local government), with the UK government responsible for employment across the country and for policies in England. Across the UK, social services are provided by local government or third sector welfare organisations and private providers mainly funded by the UK, devolved or local governments.

\footnotetext{
${ }^{3}$ The Work Programme was replaced by Fair Start Scotland and in England's Work and Health Programme.
} 


\section{Local provision of social and employment services}

The local provision of social and employability services varies between devolved administrations and cities and so are coordinated in different ways in each city. Local authorities deliver most social services, either directly or contracted-out to private or thirdsector bodies through grants, negotiation, or competitive tendering (Fuertes and McQuaid, 2016). This is, largely, consistent with the 'liberal' country classification. The roles and resources of local authorities are themselves determined by the Scottish government and Welsh administration for Edinburgh and Cardiff respectively and the UK government for Newcastle. Meanwhile, the UK-wide, centralised labour market policy is based on marketbased national logic and produces similar policies in the three cities.

Institutional logics at the local level

State: A centrally controlled JCP agency implies that benefit payments and employment services are shaped by a homogeneous framework of rules, which govern UK services interagency coordination and performance. In each city, local frameworks are developed to complement the national provision, but inter-agency coordination between administrative frameworks has encountered challenges (Table 1). For instance, particularly in Edinburgh, services funded by the local or devolved administration are not freely accessible to agencies contracted through the UK Work Programme, due partly to a fear of subsidising Work Programme providers for services they are contracted to supply (Fuertes and McQuaid, 2013). Hence differing State logics in Edinburgh compared to the other cities results in some variations in local and regional policy support and approaches to inter-agency co-operation; and arguably a more prominent role of classical social assistance and social investment orientations that may be neglected in work-first approaches.

Table 1 about here

Market: In the UK, market-based relations are prominent in the delivery of labour market policies and to a lesser extent social services. Although market relations are essential in each city, inter-agency coordination differs. In Newcastle and Edinburgh, the local authoritys' economic development department is involved in employability and anti-poverty measures and therefore business organisations are more prominent (such as chambers of commerce). Marketisation of services and New Public Management approaches were blamed for the lack of inter-agency coordination, as agencies compete for funding and to claim outcomes: "The rhetoric of partnership can be there but the way the market operates is competitive" (senior local authority official in Newcastle). Nevertheless, some argued that inter-agency coordination can be achieved through market logic in an efficient way. For example, Edinburgh's Hub Contract (City of Edinburgh Council, 2011), and to a lesser extent Newcastle Futures, achieved coordination through contract-management organisations appointed by local government.

"It seems ... that you will get far more actual on-the-ground integration from a contractual arrangement that from another 10 years' worth of encouraging collaboration (...)." (Director, Local Agency, Edinburgh) 
Professions: The professional basis of inter-organisational collaboration tends to be driven by the employability orientation and by contractual requirements especially in Edinburgh and Newcastle; partly as employability responsibilities rest within the local authority's single economic development department. However, variations in the institutional logic between cities result in differences, as Cardiff's more social work focus seems more prevalent and employability services are spread across a number of different departments. In the absence of established joint management of services for a single unemployed person, collaboration tends to be based on an ad-hoc view of the person's needs, based on their case-worker's knowledge and contacts or on local service availability. Further barriers to inter-agency collaboration revolve around organisational goals and contractual requirements, such as protecting an organisation's claim for the funding associated with positive outcomes (for example claiming that a person entering employment was due entirely to that organization's support rather than due to other organisations that also supported the individual).

"People are not so keen to share things because they have been pushed into competing with each other. If there is less money people are less likely to work cooperatively and collaborate." (Director, Third Sector Organisation, Newcastle).

Community: Community-based networks are important in the three cities, usually as a result of the traditional third sector involvement in the provision of social services. Personal relations help create and maintain these networks, in many cases developed as a result of forums, where local government and stakeholders come together: for example the 'Economy, Work, Skills and Learning partnership' in Newcastle the 'Joined Up For Jobs Strategy Group' in Edinburgh or the 'What Matters partnership strategy' in Cardiff. However, national policy structures have influenced community-based networks, with them weakening in Newcastle after the government's abolition of Local Strategic Partnerships in England in 2010. In contrast, Edinburgh's Community Planning Partnerships and Cardiff's Local Service Board brought together local stakeholders and maintained closer relations. In the three cities the role of the third sector, and their networks, have receded due to decreased funding (e.g. the end of the Working Neighbourhoods Fund in England in 2011). In summary, UK centralised policy has the effect of producing similar local patterns, with market-based inter-agency coordination being prevalent. Nevertheless, some differences can be seen between the dominance of the administrative logic in Edinburgh, the community-based logic in Cardiff, and the market-based logic dominance in Newcastle. This leads to tensions between local and national approaches. For instance, within the professions logic, Cardiff takes a more social services and public and third sector led approach with the other cities taking more economic development and employability led approaches. There are also tensions between the devolved governments and the UK level in the State logics. So despite an overall national market-based logic, considering specific logics reveals nation-local tensions.

\subsection{Germany: A diversified and disconnected pattern of service-provision}

\section{National context}


Besides the activation of short-term unemployed, which is the exclusive responsibility of the Federal Unemployment Agency (FEA) and their employment agencies, the activation of long-term unemployed and employable, but inactive persons, with multiple barriers to employment, takes place in 407 job centres, founded since 2005 . These job centres are mostly joint organisations of the FEA - a centrally coordinated bureaucratic organisation with more than 100,000 employees - and municipalities. This reflects the particular design of German unemployment assistance (ALGII) which combines two usually separated logics of unemployment insurance for individuals and minimum income protection for households. Therefore, the job centres are responsible for the payment of unemployment assistance to the respective households and for the placement and activation of unemployed not entitled to unemployment benefits (ALGI), for employed people on very low wages, for long-term unemployed and other employable, but inactive job seekers. The employees of the job centres reflect this dual, insurance- and assistance-based logic; they are often social workers from the municipalities or placement officers from the FEA. The major policy challenge in Germany is supporting the (re-)employment of the long-term unemployed (according to Eurostat, approximately $46 \%$ of all unemployed in 2012, in contrast to $22 \%$ in Sweden and $37 \%$ in the UK), which is mainly the task of the job centres. These long-term unemployed are mostly unskilled, older and immigrants. The access to activation measures is selective: only a third of the long-term unemployed participate in training, job creation and occupational integration measures. Only a fifth of them find a job. Social services play an essential role in the integration of the long-term unemployed and other disadvantaged groups (Heidenreich and Aurich-Beerheide, 2014).

\section{Local provision of social and employment services}

In Germany, social services are provided either by the municipal social welfare offices (which are also stakeholders of the job centres) or third sector welfare associations based on religious, humanitarian or political convictions. In contrast, to the highly structured and centralised provision and monitoring of employment services, social services vary considerably between municipalities (Heidenreich et al., 2014; Künzel, 2012). Halle, with the highest number and relative share of unemployment assistance beneficiaries in our sample, developed a comprehensive and collaborative strategy for dealing with this group, while in Würzburg, a wealthy southern region where this group is smaller, collaboration played only a minor and residual role amongst relevant actors (Zimmermann and Rice, 2016). In the field of employment policies and services, inter-agency collaboration in Germany is characterised by close cooperation between trade unions, employers' associations, public employment agencies, chambers of commerce and training institutions. An essential difference between the German regions is the extent to which this corporatist pattern shapes the provision of employment services and influences the patterns of cooperation in the field of social services. This is mostly the case in Oldenburg: the public administration has a strong role and unions and business associations are dominant actors in the regulation and provision of social services (Zimmermann and Rice, 2016). In addition, the local branches of the national welfare associations play an important role: they provide various types of counselling, children's and elderly services. In Würzburg, the situation is different: the church and their welfare services are crucial in that region - and also to the services provided by the social welfare office of the municipality. In Halle, the job centre is a large and highly professionalised organisation which is able to deal with the large number of 
unemployment assistance recipients in a standardised way. Due to the difficult local labour market situation, many of the unemployed people are well qualified and in principle fit to take up new jobs. Social services (child care, debt counselling, housing etc.) are provided either by the municipal welfare office or by external providers.

\section{Institutional logics at the local level}

The development and implementation of these policies is now considered based on state, market, professional and community logics.

State: The general German pattern of a centrally controlled employment agency implies that on the one hand benefit payments and the offer of employment services is shaped by a homogeneous framework of rules. A strict respect of these rules could be observed mostly in Halle and Würzburg (Table 1). On the other hand, the crucial role of corporatist actors in placement services and the municipal and third-sector provision of social services imply an important role for trade unions, business associations, welfare organisations and local politics. Therefore, the local offer of employment and social service is the result of a multilevel system which might also be shaped by local actors and patterns of cooperation. Particularly in Oldenburg, we observed a strong impact of tripartite bargaining patterns reflecting their differing state logics.

Market: Market relations play an essential role only in the provision of training and further education services (Fuertes et al., 2014: S77). According to EU rules, external providers have to be chosen through open competitive bidding. In Halle, these competitive bids are accepted as normal administrative procedures; closer links with local providers are not seen as essential for a better service quality. In Oldenburg, the local actors seem to be able to continue their traditional business relations in spite of new regulatory frameworks. In this case the provision of external services is regulated less by a market logic than an associational logic: private organisations founded by the actors of the corporatist model (business associations, trade unions, chambers of industry and commerce) and the local branches of the national welfare associations (mostly the 'Diakonie' and the CARITAS, the social service arms of the Protestant and Catholic churches) have in general privileged access to competitive tenders. In Halle business associations are a key player in the networks of provision.

Professions: The professional basis of the inter-organisational collaboration in Oldenburg and Würzburg is characterised by a strong social worker orientation. Many of the clients of the job centres are difficult to integrate into the labour market; they are mostly the target of social pedagogic interventions. The local case managers support the beneficiaries in finding accommodation or day-care. Due to close personal networks they also sometimes find jobs for disadvantaged people. In Halle, the professional culture is shaped by an orientation towards the requirements of local employers. Due to the high level of qualifications of many beneficiaries, and their large numbers, the local job centre is actually part of the municipal economic department and operates according to a professional logic. Community: Community-based networks are important in all three regions. Often, the caseworkers develop systematic relations with local partners:

"I have lived here already for a very long period and have many contacts. I even became interested in the local football club; even there you can meet the local employers; because the important people are there." (Director, Job Centre, Halle) 
These networks are based on strong regional identities which are rooted in the case of Würzburg in religious affiliations, in Oldenburg on a social-democratic political heritage and in Halle on post-socialist experiences. Particularly in the case of Oldenburg, but also in the other regions, close collaborations based on the corporatist regulation of employment policies also shape the arena of social services.

In summary, the general bureaucratic-corporatist German pattern clearly differs at the local level between the dominance of bureaucratic-administrative logics in Halle, the corporatistassociational logics in Oldenburg and the role of community-based, religious welfare associations in Würzburg. Overall these local differences in logics are not all consistent with a single dominant national institutional logic, indicating local-national tensions, at least in some cities. In terms of the relationship of social assistance and solidaristic support, Germany reduced the level of benefits for long-term unemployed thus excluding them symbolically from the moral order of solidaristic support. This was still perceived as a major threat to the lower and middle classes even 15 years later and even in the relatively wealthy communities of Würzburg or Oldenburg.

\subsection{Sweden: Centralised but differentiated patterns of service-provision}

\section{National context}

The Swedish government's 200 Public Employment Service offices implement the national labour market policies relying on in-house provision and centrally procured private 'complementing actors'. Unemployed people follow similar trajectories throughout the country, although policies are articulate differently at regional and local levels (Jacobsson et al., 2017). People register at a PES office to receive unemployment benefits or insurance, but with work incentives and contractualisation of support (Bengtsson, 2014). Those not qualifying for unemployment benefits can apply for means-tested social assistance. Services vary between the short- and long-term unemployed. Initially all unemployed receive services from the local PES office, which are gradually intensified. Individuals with marginal labour market attachment are referred to municipal services. In the large cities attempts have been made to promote area-based, multi-level actor programmes which highly value partnership working.

The national Swedish Social Insurance Agency (SSIA), through local offices, administers social security claims and assists people on sick leave back into the labour market. The 20 Swedish counties have no role in the development and implementation of labour market policies, but are important actors assisting unemployed people and those on sick leave through providing health and medical services. The 290 Swedish municipalities administer, finance and mainly deliver social services; and therefore have incentives to activate unemployed people who do not qualify for unemployment benefits or sick benefits. Complementing the work of the PES, municipalities offer programmes for the unemployed when the required support is not available through national agencies, such as in some areas help move more disadvantaged job seekers towards paid employment through coaching or practical work experience.

Local provision of social and employment services 
Due to national regulations, the organisation of work by local offices of national agencies is structured similarly in all three localities: unemployed social assistance beneficiaries have to participate in local activation policies as a condition of receiving social assistance. In each city, the organisations assessing social assistance have merged with the units responsible for implementing labour market programmes, but each has implemented a different path in tackling unemployment (see Hollertz et al., 2013).

Inter-agency coordination is expected between public actors, and between employment policies and services (e.g. basic employment support for those with health issues or disabilities), reflecting Sweden's social democratic welfare regime - in spite of the shift "towards more rigorous activation" (Jacobsson et al., 2017: 91; Bengtsson, 2014). Public actors still dominate although, as in other European countries, New Public Management and the marketisation of public services has occurred. Coordination between services often takes place at case worker level, as it is an important part of their profession: 'there are long traditions of coordination at case worker level in Sweden' (Hollertz et al., 2013: 14). Despite similarities, inter-agency coordination differs between the three cities studied ( Jacobsson et al., 2017; Table 1).

\section{Institutional logics at the local level}

State: A universalistic state logic is reflected in administrative rules and resources in the three cities creating Coordination Unions, which are seen as platforms for flexible working between agencies (Table 1). Coordination Unions (based on a 2003 law) are where the PES, SSIA, the region (health care competences) and the municipality (social services competences) come together regularly to coordinate their work around work rehabilitation of disadvantaged individuals (Jacobsson et al., 2017). They are a national multi-level organisational creation where national directives and local policies, actors, issues. In them, the co-production of initiatives (for more disadvantaged individuals) is achieved through financial pooling. However, they are used in slightly different ways, being stronger in city S3 where they form the main coordination structure, as ' $a$ flexible and generous interpretation of the law is made when defining the tasks', with acknowledgement and trust between participating agencies and a mutual commitment to a 'work strategy' (Hollertz et al., 2013: 11).

"This is a work line. It is very much about close cooperation with other agencies... (...) and how we try to synchronise our activities in relation to PES, SSIA, and health care. It is all about attracting employers and to make them want to [get] employment and to make them dare to [be] employed." (Municipality, city S3)

Reflecting differences in local institutional logics, other mergers have also made coordination possible, for example in S3 the economic development unit is in the department responsible for activation policies and adult learning. This is likely to influence the inter-agency coordination between private businesses and the local administration in relation to activation policies.

Market: There are national directives on the contractualisation of labour market policies for the long-term unemployed and the private sector is seen as an important partner. However, public actors are key to the development of policies (administrative rules/sources), partly in order to avoid duplication of services but also to control the construction of solutions to 
problems (Hollertz et al., 2013: 23). Nevertheless, in each city the key actors in inter-agency collaboration differ significantly. In city S3 (the most buoyant economy), the dominant actors are mainly private providers, while in city $\mathrm{S} 2$ the tradition is to provide activation policies through third sector organisations and networks established to do so, while in city S1 (the worst performing economy) public actors dominate. However, privatisation of some policy areas, according to Hollertz et al. (2013), results in limited inter-agency coordination due to a 'lack of financial incentives', and in some cases negative incentives due to competition.

Professions: In cities S1 and 2 professional boundaries and competences are highlighted by national agencies making inter-agency coordination more conflict ridden than in city S3. In that city there is a high level of trust between actors and an acknowledgement of the value of coordination. For example, an unemployed individual receiving social assistance is referred automatically to local activation policies (called the 'Work Line'), while in cities S1 and 2 that referral is based on professional judgement. There are also clear differences between the cities in terms of the orientation of activation policies. City S3's work-first approach aims to promote "healthy and entrepreneurial residents" with an underlying expectation of increasing benefits conditionality and quick exit from unemployment to employment; whereas city S1 leans towards a life-first approach aiming to create "meaningful occupation/activation" for the unemployed, not necessarily in the regular labour market; and in city S2 the approach is somewhere in between these two (Jacobsson et al., 2017: 95).

Community: Community-based networks are common in Sweden, with long traditions of creating arenas for agencies at different administrative levels to come together and discuss 'common areas of concern related to labour market and activation policies' (Hollertz et al., 2013: 12). Coordination Unions should have made other 'traditional' coordinating structures irrelevant. However, in cities S1 and 2 previous networks remain in place within or alongside these unions, suggesting how differences in, or changes to, institutional logics can lead to tensions. In city S2, a coordination centre for the third sector was established already in the 1980s.

In summary, notwithstanding the considerable inclusiveness of activation policies and their homogeneity across the national territory; due to central administrative rules "local worlds of activation" in Sweden (Jacobsson et al., 2017) differ between the dominance of community-based logic with third sector networks in city S2, bureaucratic-administrative logics in city S1, and a market-based logic in city S3. Again, these local differences suggest some degree of tension with the dominant national institutional logics, even in a relatively homogenous country.

\section{Discussion and Conclusions}

In each country there were differences between specific local and national institutional logics, leading to variations in policy delivery and inter-agency working, even where the dominant institutional logics were consistent. In terms of the logics of linking social assistance and activation for those with multiple employment barriers, the UK appears as a combination of both activation logic with strong conditionality and sanctions with a shift to individualised, holistic support and training both to improve employability (activation) and to compensate for failures in acquiring skills. Meanwhile specific groups (such as some jobseekers with disabilities) join the Work Programme on a voluntary basis and continue to 
receive full benefits, and so fall within the social assistance logic. In Germany, activation logics were extended to employable persons who previously would have received social assistance, contributing to an important increase in labour market flexibility and an expansion of low-wage jobs especially in Eastern Germany and in particular Halle. In Sweden the logic of stigmatizing assistance described by Coser (1965) had long been replaced by inclusive, rights-based policies which facilitated comprehensive, professionalised activation policies implemented by agencies at different administrative levels.

In some cases, the dominant institutional logics differed between national and local levels, particularly in Germany, while in others main national-local differences and tensions occurred within each institutional logic. In all cases there were differences in the dominant logics between cities within each country.

A first conclusion is that in terms of the focus of this study, i.e. unemployment and benefits assistance to unemployed job seekers with multiple and severe barriers to work, the general institutional logics framework should be adapted, with the "state logic" encompassing a political and a bureaucratic-administrative component. The latter is particularly important for service provision. Similarly, the professional logic encompasses both a competencebased and a corporatist-associational logic; the latter one being particularly important due to the roles of business, labour, third sector and welfare associations.

Second, national governance frames play a decisive role in local inter-organisational coordination of activation policies. In the $U K$, a centralised national policy framework with a focus on market relations has the effect of regulating local practices along similar patterns. In Germany, a centralised employment policy with a focus on the bureaucratic administration of unemployment, shapes local employment and services to deliver activation policies along similar patterns. In addition, inter-organisational coordination in labour market policies is traditionally high due to corporatist bargaining patterns between employers and business associations, unions, public agencies, and chambers of industry and commerce as they negotiate new policy developments. In the field of social policies and services, municipalities and welfare associations, together with the local branch of the Federal Employment Agency, are essential actors. Market relations play a minor role. In Sweden the differences between the three cities, in both labour market policy and social assistance, are relatively small due to the centralised national directives and regulation and standard municipal laws and regulations, together with normative pressure in both policy fields (Jacobsson et al., 2017). Inter-organisational coordination is mainly embedded in a universalistic state logic.

Third, in spite of these nationally homogeneous frameworks, the inter-organisational coordination in the delivery of activation policy services varies between cities within each country which might reflect different local values attached to the previously mentioned moral orders of social assistance and solidaristic support. Using institutional logics as a framework helps explain the prevalence of different types of "local politics, established local traditions, patterns of networking and modes of collaborating" (Jacobsson et al., 2017: 86). In the UK differences between cities are not large, with market governance being prevalent and an emphasis on employability as a result of outcome-based contracts requiring services to focus on improving labour market participation. However, patterns of delivery have specific local characteristics. While in Cardiff, and to some extent Edinburgh, the pattern is embedded in a social context where community and partnerships are important, in Newcastle (the worst performing economy) community-based relations in inter-agency coordination are less systematic and established. In Newcastle and Edinburgh business 
associations are a significant part of the networks, while in Cardiff the third sector appears more prominent.

In Germany, the bureaucratic-corporatist governance of labour market policies at the national level influences all cities. However, at the local level the job centres have considerable leeway in shaping local networks of service provision between the moral orders of social assistance and solidaristic support as discussed above. In Würzburg the church, and its organisations and networks, plays an important role. In Oldenburg, all social actors, but especially the trade unions, are the key players in stable corporatist networks of provision. In Halle business associations are integrated as key actors in close networks of service provision. In Sweden labour market policies are centralised. Nevertheless, networks of provision - within the context of the Coordination Unions - vary amongst cities: in city S3 administrative rules have brought in businesses as key actors in service provision in close public and private networks embedded in a work-first approach. In city S2, where the third sector is traditionally an important actor in various loose networks, sometimes coordination is based on administrative rules. Meanwhile in city S1 public actors are key inservice providers in relatively close networks.

In summary, the four selected institutional logics (state, markets, professions, community) are crucial for the provision of collective goods and local conventions across all the UK, German, and Swedish cities. Although all three countries are characterised by centralised employment policies, they have created local forums (e.g. Edinburgh's Strategy Group), organisations (e.g. German job centres) and arenas (e.g. Swedish Coordination Unions) for accessing local competences, resources, and patterns of coordination. Within this national context, all cities have developed hybrid institutional logics. Community-based logic is more prominent in Würzburg, Cardiff, and city S2; in Edinburgh, Halle and city S1 a state logic is more apparent; market coordination is more prominent in city S3 and Newcastle and; a professional-corporatist logic is more visible in Oldenburg (Table A2 in the online appendix). These differences in institutional logics help explain the variations in how public, third and private sectors interact and co-ordinate provision of employment and related welfare services. Hence, in each country the local institutional logics related to activation policy have been shown to vary between cities, and between cities and the national institutional logic, leading to national-local tensions in the development of policies, their delivery and interagency working.

These "local worlds of activation" (Heidenreich and Aurich-Beerheide, 2014; Jacobsson et al., 2017) can partly be explained by different traditions and relative cultural understandings and weights of social and employment support, challenges and governance structures. First, past traditions of collaboration and established understandings of welfare and activation might shape current patterns. For example, in Würzburg, the church and its concept of help and social assistance has a prominent role in the community, while in Oldenburg with its strong corporatist traditions, employment-related social actors are very important. Second, different local unemployment levels, and the related coordination needs, influence the type of service delivery. For example, city S3 has low unemployment but a high percentage of people on social assistance, which partly explains its work-first approach and the dominant role of market governance, which insists on the mutual obligations of donors and benefit recipients instead of an unconditional, but stigmatising assistance. Finally, different patterns of national decentralisation and local autonomy influence inter-agency coordination. For example, in Edinburgh and Cardiff the devolved policy power to national/regional 
governments in some social policy areas has meant that systematic forms of interorganisational coordination have been established, while at the same time there are coordination problems between devolved areas and the highly centralised UK labour market policy.

In summary, the use of an institutional logics framework highlights and helps our understanding of the tensions and potential conflicts in each country in the delivery of activation policy for the most disadvantaged job seekers; and also of inter-agency working between cities and between the cities and the predominant national logics. The local implementation of activation policies is significantly influenced by national frameworks of governance. Inter-organisational coordination is shaped in the UK by market-based logics and relations, in Germany by bureaucratic-corporatist bargaining patterns and in Sweden by bureaucratic-universalist logics. Although all three countries are characterised by centralised employment policies, local institutions significantly affect policy development and implementation on the ground. Different cities within each country have evolved different combinations of community-, professional-, state- and market-based logics for interagency collaboration in the provision of employment and social services, which in turn partly reflects the additional formal and informal resources they allow access to in relation to the national framework. This can in part be explained by path dependencies, different local challenges, and different national-local relations. In addition, institutional logics help to explore the differences between employment support and social support in activation policies, showing how different balances between the two may influence inter-agency working at the local level, as well as indicating potential conflicts with dominant national policy logics.

An important question is whether differing local institutional logics reflect, or inhibit, appropriate policy delivery responses to the local context and local circumstances? Although we did not systematically measure the effectiveness of local activation policies, there is no evidence for a universally applicable logic for a successful local activation policy. The cities with the lowest (long-term) unemployment rates (see Table 1) rely on market-based (city S3), state-based (Edinburgh) and community-based (Würzburg) logics, while those with the highest unemployment rates, which have to deal with the crises of their old industrial structures, rely on state- and market-based logics (city S1, Newcastle, and Halle). While the latter logics correspond to the national pattern, the cities with employment at or above the national average exploit the specific institutional resources of their region: in a statedominated context, coordination based on markets (city S3), communities (Würzburg; city S2) or professions (Oldenburg); while in a market-oriented national context, the additional usage of communitarian (Cardiff) or public coordination (Edinburgh) is linked with better coordination results. A strength of local activation policies therefore may consist in institutional logics which are complementary to the national patterns and which facilitate the access to additional networks, experiences, and motivations in relation to the national framework.

Finally, further research is needed on the links between, and differing importance of, the use of these different logics and their policy effectiveness, and on how differing socioeconomic and political contexts influence the institutional logics. 
Acknowledgements: The research leading to these results received funding from the European Union's Seventh Framework Programme under grant agreement no. 266768. The three national teams who conducted these case studies are listed in Heidenreich and Rice, 2016: 14. We are particularly grateful for the consent of our Swedish colleagues to use their results (cf. Jacobsson et al., 2017). All errors remain those of the authors.

\section{References}

Bayertz, K. (1999) 'Four uses of "Solidarity"', in K. Bayertz (ed.) Solidarity, pp. 3-28. Dordrecht: Springer.

Bengtsson, M. (2014) 'Towards standby-ability: Swedish and Danish activation policies in flux', International Journal of Social Welfare 23(1): S54-S70.

City of Edinburgh Council (2011) New commissioning strategy for council supported employability services: Report no CEC/52/11-12/CD. Edinburgh.

Coser, L. A. (1965) 'The sociology of poverty: To the memory of Georg Simmel', Social Problems 13(2): 140-8.

Eichhorst, W., Kaufmann, O. and Konle-Seidl, R. (2008) Bringing the jobless into work?: Experiences with activation schemes in Europe and the US. Berlin, Heidelberg: Springer.

Esping-Anderson, G. (1990) 'The three worlds of welfare capitalism'. Princeton, NJ: Princeton University Press.

European Commission (2019) Evaluation of the Council Recommendation on the integration of the long-term unemployed into the labour market. Brussels.

Fuertes, V., Jantz, B., Klenk, T. and McQuaid, R. (2014) 'Between cooperation and competition: the organisation of employment service delivery in the UK and Germany', International Journal of Social Welfare 23(S1): S71S86.

Fuertes, V. and McQuaid, R. (2013) The Work Programme: A new public governance policy or a continuation of new public management? Fondazione Volontariato e Partecipazione, Working Paper Series PVeP 20.

Fuertes, V. and McQuaid, R. (2016) 'Personalized activation policies for the long-term unemployed: The role of local governance in the UK', in M. Heidenreich and D. Rice (eds) Integrating social and employment policies in Europe, pp. 93-117. Cheltenham, Northampton/MA: Edward Elgar.

Heidenreich, M. and Aurich-Beerheide, P. (2014) 'European worlds of inclusive activation: The organisational challenges of coordinated service provision', International Journal of Social Welfare 23(S1): 6-22.

Heidenreich, M., Petzold, N., Natili, M. and Panican, A. (2014) 'Active inclusion as an organisational challenge: Integrated anti-poverty policies in three European countries', Journal of International and Comparative Social Policy 30(2): 180-98.

Heidenreich, M. and Rice, D. (eds.) (2016) Integrating social and employment policies in Europe. Cheltenham, Northampton/MA: Edward Elgar.

Hollertz, K., Garsten, C. and Jacobsson, K. (2013) The local governance of social cohesion: Sweden Country Analysis. Report produced for LOCALISE, EU Seventh Framework Programme. Stockholm.

Jacobsson, K., Hollertz, K. and Garsten, C. (2017) 'Local worlds of activation: The diverse pathways of three Swedish municipalities', Nordic Social Work Research 7(2): 86-100.

Kazepov, Y. (2008) 'The subsidiarization of social policies: Actors, processes and impacts. Some reflections on the Italian case from a European perspective', European Societies 10(2): 247-73.

Kazepov, Y. (ed.) (2010) Rescaling social policies: towards multilevel governance in Europe. Farnham: Ashgate.

Künzel, S. (2012) 'The local dimension of active inclusion policy', Journal of European Social Policy 22(1): 3-16.

Leibfried, S. and Tennstedt, F. (1985) 'Armenpolitik und Arbeiterpolitik', in S. Leibfried (ed.) Politik der Armut und die Spaltung des Sozialstaats. Frankfurt am Main: Suhrkamp.

Linden, R. M. (2002) Working across boundaries: Making collaboration work in government and nonprofit organizations. San Francisco: Jossey-Bass.

Lindsay, C., McQuaid, R. W. and Dutton, M. (2008) 'Inter-agency cooperation and new approaches to employability', Social Policy \& Administration 42(7): 715-32. 
McQuaid, R. W. and Lindsay, C. (2005) 'The concept of employability', Urban Studies 42(2): 197-219.

Serrano Pascual, A. (2007) 'Reshaping welfare states: Activation regimes in Europe', in A. Serrano Pascual and L. Magnusson (eds) Reshaping welfare states and activation regimes in Europe, pp. 11-34. Bruxelles: P.I.E. Lang. Skelcher, C. and Smith Rathgeb, S. (2015) 'Theorizing hybridity: Institutional logics, complex organizations, and actor identities: The case of nonprofits', Public Administration 93(2): 433-48.

Thornton, P. H., Ocasio, W. and Lounsbury, M. (2012) The institutional logics perspective: A new approach to culture, structure, and process. Oxford: Oxford University Press.

Vickers, I., Lyon, F., Sepulveda, L. and McMullin, C. (2017) 'Public service innovation and multiple institutional logics: The case of hybrid social enterprise providers of health and wellbeing', Research Policy 46(10): 175568.

Zimmermann, K. and Rice, D. (2016) 'Organisational barriers to service integration in one-stop-shops: The case of Germany', in M. Heidenreich and D. Rice (eds) Integrating social and employment policies in Europe, pp. 162-84. Cheltenham, Northampton/MA: Edward Elgar. 
Table 1. Social bases of interagency collaboration in the field of social services.

\begin{tabular}{|c|c|c|c|c|c|c|c|c|c|}
\hline & Newcastle & Cardiff & Edinburgh & Halle & Oldenburg & Würzburg & City S1 & City S2 & City S3 \\
\hline State & $\begin{array}{l}\text { Limited } \\
\text { coordination } \\
\text { facilitates } \\
\text { market } \\
\text { relations } \\
\text { facilitate }\end{array}$ & $\begin{array}{l}\text { Devolved } \\
\text { administrative } \\
\text { rules/resources } \\
\text { facilitate } \\
\text { limited } \\
\text { coordination }\end{array}$ & $\begin{array}{l}\text { Devolved } \\
\text { administrative } \\
\text { rules facilitate } \\
\text { coordination } \\
\text { and wide } \\
\text { networks based } \\
\text { on market } \\
\text { relations } \\
\end{array}$ & $\begin{array}{l}\text { Strict } \\
\text { conformity with } \\
\text { formal rules }\end{array}$ & $\begin{array}{l}\text { Established } \\
\text { patterns of } \\
\text { cooperation } \\
\text { (lower } \\
\text { importance of } \\
\text { formal rules) }\end{array}$ & $\begin{array}{l}\text { Fear of control: } \\
\text { strict obedience } \\
\text { to formal rules }\end{array}$ & $\begin{array}{l}\text { Established } \\
\text { rules of } \\
\text { cooperation but } \\
\text { multiple } \\
\text { network } \\
\text { structures }\end{array}$ & $\begin{array}{l}\text { Established } \\
\text { rules of } \\
\text { cooperation but } \\
\text { multiple } \\
\text { network } \\
\text { structures }\end{array}$ & $\begin{array}{l}\text { Rules of } \\
\text { cooperation } \\
\text { between } \\
\text { agencies }\end{array}$ \\
\hline Market & $\begin{array}{l}\text { Important role } \\
\text { of private } \\
\text { providers }\end{array}$ & $\begin{array}{l}\text { Third sector } \\
\text { important in } \\
\text { implementation } \\
\text {, but also public } \\
\text { and private } \\
\text { organisations }\end{array}$ & $\begin{array}{l}\text { Public, private, } \\
\text { and third sector } \\
\text { providers have } \\
\text { important roles } \\
\text { in service } \\
\text { delivery }\end{array}$ & $\begin{array}{l}\text { Limited to } \\
\text { education and } \\
\text { training; less } \\
\text { important role } \\
\text { of external } \\
\text { providers in } \\
\text { project } \\
\text { development }\end{array}$ & $\begin{array}{l}\text { Limited to } \\
\text { education and } \\
\text { training; } \\
\text { external } \\
\text { providers } \\
\text { generally linked } \\
\text { to unions, } \\
\text { business } \\
\text { associations } \\
\text { and welfare } \\
\text { organisations }\end{array}$ & $\begin{array}{l}\text { Limited to } \\
\text { education and } \\
\text { training; } \\
\text { external } \\
\text { providers in } \\
\text { general linked } \\
\text { to church and } \\
\text { its welfare } \\
\text { services }\end{array}$ & $\begin{array}{l}\text { public actors } \\
\text { important in the } \\
\text { development } \\
\text { and } \\
\text { implementation } \\
\text { in comparison } \\
\text { to external } \\
\text { actors }\end{array}$ & $\begin{array}{l}\text { Important } \\
\text { external } \\
\text { providers from } \\
\text { the third sector } \\
\text { in } \\
\text { implementation }\end{array}$ & $\begin{array}{l}\text { Crucial role of } \\
\text { external private } \\
\text { providers in } \\
\text { implementation }\end{array}$ \\
\hline Professions & $\begin{array}{l}\text { Work-first } \\
\text { approaches } \\
\text { and silo } \\
\text { policy fields }\end{array}$ & $\begin{array}{l}\text { Work-first } \\
\text { approaches and } \\
\text { silo policy } \\
\text { fields }\end{array}$ & $\begin{array}{l}\text { Work-first } \\
\text { approaches and } \\
\text { silo policy } \\
\text { fields }\end{array}$ & $\begin{array}{l}\text { Focal role of } \\
\text { public } \\
\text { administration } \\
\text { and economic } \\
\text { considerations }\end{array}$ & $\begin{array}{l}\text { Dominant role } \\
\text { of social } \\
\text { pedagogic } \\
\text { orientations }\end{array}$ & $\begin{array}{l}\text { Dominant role } \\
\text { of social } \\
\text { pedagogic } \\
\text { orientations }\end{array}$ & $\begin{array}{l}\text { Dominant life- } \\
\text { first approach } \\
\text { with clear } \\
\text { professional } \\
\text { boundaries }\end{array}$ & $\begin{array}{l}\text { Between life- } \\
\text { and work-first } \\
\text { approaches. } \\
\text { Agencies are } \\
\text { protective of } \\
\text { boundaries }\end{array}$ & $\begin{array}{l}\text { Dominant } \\
\text { work-first, } \\
\text { standardise } \\
\text { referrals and } \\
\text { high inter- } \\
\text { agency } \\
\text { coordination }\end{array}$ \\
\hline Community & $\begin{array}{l}\text { Scarce } \\
\text { networks } \\
\text { based on } \\
\text { market } \\
\text { relations }\end{array}$ & $\begin{array}{l}\text { Relatively loose } \\
\text { networks based } \\
\text { on devolved } \\
\text { administrative } \\
\text { rules/resources }\end{array}$ & $\begin{array}{l}\text { Relatively close } \\
\text { networks based } \\
\text { on market } \\
\text { relations and } \\
\text { devolved } \\
\text { administrative } \\
\text { rules/resources }\end{array}$ & $\begin{array}{l}\text { Close relations } \\
\text { (based on } \\
\text { regional } \\
\text { identity) }\end{array}$ & $\begin{array}{l}\text { Very close } \\
\text { (based on } \\
\text { corporatist } \\
\text { collaboration) }\end{array}$ & $\begin{array}{l}\text { Relatively loose } \\
\text { (based on } \\
\text { regional and } \\
\text { religious } \\
\text { identity) }\end{array}$ & $\begin{array}{l}\text { Relatively close } \\
\text { but conflicting } \\
\text { networks: based } \\
\text { on } \\
\text { administrative } \\
\text { rules and other } \\
\text { traditional } \\
\text { structures }\end{array}$ & $\begin{array}{l}\text { Relatively close } \\
\text { but conflicting } \\
\text { networks: based } \\
\text { on } \\
\text { administrative } \\
\text { rules and other } \\
\text { traditional } \\
\text { structures }\end{array}$ & $\begin{array}{l}\text { Close networks } \\
\text { of public and } \\
\text { private } \\
\text { providers based } \\
\text { on } \\
\text { administrative } \\
\text { rules and trust }\end{array}$ \\
\hline
\end{tabular}

